\title{
Atıksu Arıtma Tesisinde Çözünmüş Organik Azotun Biyolojik Parçalanabilirliğinin İncelenmesi
}

\author{
Sezen KÜÇÜKÇONGAR ${ }^{1 *}$, Ayşe SEVİL ${ }^{1}$ \\ ${ }^{1}$ Çevre Mühendisliği Bölümü, Mühendislik ve Doğa Bilimleri Fakültesi, Konya Teknik Üniversitesi, Konya, Türkiye \\ ${ }^{* 1}$ skucukcongar@ktun.edu.tr
}

(Geliş/Received: 04/11/2019;

Kabul/Accepted: 29/05/2020)

Öz: Atıksu arıtma tesisleri (AAT) çıkışındaki çözünmüş azot, inorganik ve organik formları içermektedir. Nitrifikasyon/denitrifikasyon prosesleri ile donatılmış olan AAT'de yüksek çözünmüş inorganik azot (ÇİA) giderimi (\%95'in üzerinde) gerçekleştirilebilmektedir. Son yapılan çalışmalar AAT çıkışlarında çözünmüş organik azotun (ÇOA), toplam çözünmüş azot (TÇA) içerisinde önemli bir kısmı oluşturduğunu ve genellikle bu aralığın çıkış TÇA'nın \%25-80'i olduğunu göstermiştir. Kompleks oluşu nedeniyle, ÇOA verildiği sucul ortamlarda, azotlu dezenfeksiyon yan ürünleri için öncü bileşik olarak, bakteri, alg gelişiminde nutrient olarak davranabilir, çözünmüş oksijeni tüketebilir, membran bozulması, ötrofikasyon ve diğer nitrifikasyon konularında reaksiyonlara katılabilir. Bunların bir sonucu olarak, atıksu arıtımında ÇOA yönetimi önemli bir konudur. Biyolojik parçalanabilen ÇOA (BÇOA), ÇOA'un belirli karışık bakteri kültürü tarafindan mineralize edilebilen kısmıdır. Bu çalıșmada, ÇOA ve BÇOA'nın 4 bölmeli Bardenpho prosesi bulunan bir atıksu arıtma tesisinde arıtım hattı boyunca değişimi incelenmiştir. Arıtma tesisinde farklı noktalardan temin edilen atıksu örneklerinin biyolojik parçalanabilirliğinin belirlenebilmesi için 28 günlük inkübasyon prosedürünün öncesinde ve sonrasında çözünmüş azot türleri (Kjeldahl, amonyak, nitrit ve nitrat azotu) analiz edilmiştir. ÇOA değerleri ön arıtım çıkışında 1,9-56,76 mg/L ve AAT çıkışında 4,1-19,7 mg/L aralığında tespit edilmiştir. Karışık bakteri kültürü kullanılarak atıksu örneklerinde biyolojik parçalanabilirlik incelenmiş ve AAT arıtım hattında farklı örnekleme zamanlarında \%26-98 aralığında belirlenmiştir. BÇOA/TÇA oranı \%6-85 aralığında bulunmuştur.

Anahtar kelimeler: Çözünmüş organik azot (ÇOA), biyolojik parçalanabilen çözünmüş organik azot (BÇOA), atıksu arıtma tesisi (AAT).

\section{The Investigation of Biodegradability of Dissolved Organic Nitrogen in Wastewater Treatment Plant}

\begin{abstract}
Dissolved nitrogen in wastewater treatment plant (WWTPs) effluent includes inorganic and organic forms. High dissolved inorganic nitrogen (DIN) removal (more than 95\%) was able to achieve in WWTPs equipped with nitrification/denitrification processes. Recent studies indicate that dissolved organic nitrogen (DON) represents a significant portion of the total dissolved nitrogen (TDN) in WWTPs's effluent and generally ranging from $25 \%$ to $80 \%$ of the effluent TDN. Because of its complexity, DON may act as a nitrogenous disinfection by-product precursor, a nutrient for bacterial, algal growth, consume dissolved oxygen in the receiving waters; can participate in reactions that lead to membrane fouling, eutrophication and other nitrification issues. As a result of these concerns, management of DON is important issue for wastewater treatment. Biodegradable DON (BDON) is a portion of DON that can be mineralized by an acclaimed mixed bacterial culture. In this study, the fate of DON and BDON along the treatment trains of wastewater treatment plant including 4-stage Bardenpho process was investigated. Dissolved nitrogen species (Kjeldahl, ammonia, nitrite and nitrate nitrogen) were analyzed before and after 28-day incubation procedure for to determine the biodegradability of wastewater samples obtained from different sampling points in WWTP. DON values were determined between 1,9-56,76 $\mathrm{mg} / \mathrm{L}$ in effluent of primary treatment and 4,1-19,7 mg/L in effluent of WWTP. The biodegradability of wastewater samples were determined by using a mixed bacteria culture and identified between $26 \%-98 \%$ for different sampling time at WWTP treatment train. BDON/TDN ratio was found in $6 \%-85 \%$ ranges.
\end{abstract}

Key words: Dissolved organic nitrogen (DON), biodegradable dissolved organic nitrogen (BDON), wastewater treatment plant (WWTP).

\section{Giris}

Nutrient giderimi ile ilgili son yıllarda yapılan çalışmalarda, nitrifikasyon-denitrifikasyon sistemleri ile donatılmış atıksu arıtma tesislerinde yüksek inorganik azot gideriminin sağlanabildiği, ancak bu tesislerin organik azot gideriminde daha düşük etkinliğinin olduğu gözlenmiştir. Bu nedenle atıksu arıtma tesisi çıkışında

\footnotetext{
${ }^{*}$ Sorumlu yazar: skucukcongar@ktun.edu.tr. Yazarların ORCID Numaras1: ${ }^{1}$ 0000-0001-6444-4397, ${ }^{2}$ 0000-0003-3653-0874
} 
toplam çözünmüş azotun büyük bir kısmını çözünmüş organik azot oluşturmaktadır. Klasik atıksu arıtma tesisleri çıkış sularında, çözünmüş azotun yaklaşık \%65'lik kısmını çözünmüş organik azot oluşturmaktadır, nitrifikasyon-denitrifikasyon sistemlerinde bu oran daha da yüksek olabilmektedir [1-2]. Son yıllarda yapılan çalışmalar çözünmüş organik azotun içerisinde farklı formların bulunduğunu ve bunların bir kısmının ulaştıkları sucul ortamda bakteriler, doğal alg ve planktonların biyolojik olarak kullanımları için uygun olabileceğini göstermiştir [2, 3-5]. Bununla ilişkili olarak, çözünmüş organik azotun, verildiği sucul ortamlarda, ötrofikasyon, membranlarda bozulma ve dezenfektan maddeler ile birleşmesi halinde azotlu dezenfeksiyon yan ürünlerinin oluşumuna katkı sağlama gibi pek çok olumsuz etkisi vardır. Çözünmüş organik azotun bir kısmı (amino asitler gibi) verildikleri ortamda doğrudan alglerin biyolojik olarak kullanımı için, bazı formları ise bakteriyel bozunmadan sonra kullanımı için uygun olacaktır. Biyolojik olarak parçalanabilen azotun, karışık bakteri kültürleri tarafından mineralize olabilen veya doğrudan/dolaylı olarak sucul bitki türleri tarafından azot kaynağı olarak kullanıma uygun olabilen fraksiyonları mevcuttur [2-6]. Literatürde bu fraksiyonların atıksu çıkışında ve sucul ortamlarda incelendiği çalışmalar bulunmakla birlikte, atıksu arıtma tesislerinin prosesleri içerisinde giderim verimlerinin incelendiği çok az çalışma mevcuttur [2, 4-5].

Sattayatewa ve arkadaşları tarafından yapılan çalışmada [4] dört basamaklı bir Bardenpho prosesi hattı boyunca biyolojik olarak yararlanılabilen çözünmüş organik azot miktarları incelenmiş ve çıkış çözünmüş organik azotun \%28-57'sinin biyolojik olarak kullanılabilir olduğu raporlanmıştır. Çözünmüş organik azotun biyolojik olarak algler ve bakteriler tarafından birlikte kullanılabilirliği ve sadece bakteriler tarafından parçalanabilirliği arasında çok önemli bir fark gözlenmemiş, ancak tüketim hızları sırasıyla 0,13 gün $^{-1}$ ve 0,04 gün ${ }^{-1}$ olarak tespit edilmiştir. Böylece alg ve bakteri arasındaki ortak yaşam ilişkisi ve biyolojik olarak yararlanılabilen organik azot prosedüründeki inkübasyon süresinin kısaltılması da raporlanmıştır. Biyolojik olarak yararlanılabilen organik azot prosedüründeki alg ve bakteri arasındaki ortak yaşam ilişkisi ile ilgili başka çalışmalarda da aynı sonuçlar elde edilmiştir [3, 7]. Damlatmalı filtre bulunan atıksu arıtma tesisi çıkışında algler için çözünmüş organik azotun biyolojik olarak kullanılabilen kısmı \%40 kadar olup, bakteri ve alg birlikteyken bu değer \%60 kadardır [7].

Şimşek ve ark. [5] damlatmalı filtre bulunan bir tesiste inceleme yapmışlar ve biyolojik olarak parçalanılabilen çözünmüş organik azotun, ham atıksu numunesinde ve arıtma tesisinin çeşitli ünitelerinden alınan numunelerde \%51 ile \%69 arasında olduğunu bulmuşlardır. Şimşek ve ark. tarafından yapılan başka bir çalışmada [2], ön çökeltim sonrasından tesis çıkışına kadar, biyolojik olarak parçalanabilen çözünmüş organik azotun, aktif çamur tesisinde \%68'i ve damlatmalı filtre tesislerinde \%65'i giderilmiştir. Tesis çıkıs suyunda bulunan çözünmüş organik azotun, aktif çamur tesisinde \%26's1, damlatmalı filtre tesisinde \%62'si biyolojik olarak parçalanabilir formda olduğu belirlenmiştir.

Atıksu arıtma tesislerinin çıkış sularının verildikleri ortamlarda farklı su kalite parametreleri üzerinde olumsuz değişikliklere neden olabilme ihtimalleri bulunmaktadır. Azotun farklı formlarının belirli konsantrasyonların üzerinde olması suda yaşayan canlılar ve bitkilerin bozunuma katkılarıyla negatif sonuçlar oluşturabilecektir. Özellikle organik azotun sudaki farklı türler tarafından biyolojik parçanabilirliği arıtma tesilerinde organik azotun takibini daha da önemli kılmaktadır. Bu çalışmada, organik ve inorganik azot türlerinin ve buna bağlı olarak çözünmüş organik azot (ÇOA) ve biyolojik parçalanabilen çözünmüş organik azot (BÇOA)'nın 4 bölmeli Bardenpho prosesi bulunan bir atıksu arıtma tesisinde arıtım hattı boyunca değişimi incelenmiştir.

\section{Materyal ve Yöntem}

Çalışmada kullanılan atıksu numuneleri, karbon ve azotun kısmi giderimine göre tasarlanmış olan ileri biyolojik arıtım metodunun uygulandığı Konya Atıksu Arıtma Tesisi'nden alınmıştır. 1.000 .000 kişi eşdeğeri ve $200.000 \mathrm{~m}^{3} /$ gün ortalama atıksu debi değerine göre dizayn edilen atıksu arıtma tesisi, kaba ve ince 1zgaralar, havalandırmalı kum ve yağ tutucu, ön çökeltme havuzları, Bardenpho prosesi biyolojik arıtım ünitesi, son çökeltme havuzları, çamur yoğunlaştırma havuzları, anaerobik çamur çürütme tankları, çamur susuzlaştırma üniteleri (santrifüj dekantör) ve açık kanal UV dezenfeksiyon sisteminden oluşmaktadır. Tesiste biyolojik arıtım havuzları, biyolojik olarak karbon ve azotun kısmi giderimi esasına göre tasarlanmıştır.

Çalışma için gerekli numuneler atıksu arıtma tesisinden birer ay aralıklarla üç kez olmak üzere 3 farklı noktadan alınmıştır. Numune alım noktaları; ön çökeltme havuzu çıkışı (N1 örnekleme noktası), biyolojik arıtım ünitesi (ilk aerobik bölme çıkışı) (N2 örnekleme noktası) ve son çökeltme çıkışı (dezenfeksiyon öncesi) (N3 örnekleme noktası) olmak üzere tesisteki azot gideriminde önemli üç noktadır. Alınan atıksu örnekleri laboratuvara getirilerek $0.20 \mu$ hidrofilik polietersülfon membran filtreden geçirilmiştir. Süzülen numunelerde çözünmüş formdaki toplam Kjeldahl azotu, amonyak, nitrit ve nitrat azotu analizleri yapılmıştır. Daha sonra biyolojik parçalanabilirliği belirleyebilmek amacıyla inkübasyon işlemi gerçekleştirilmiştir. Literatürdeki test 
prosedürlerine uygun olarak 28 günlük inkübasyon işleminden sonra, atıksu örneklerinde aynı analizler tekrarlanmıştır.

Toplam Kjeldahl azotu (TKA) analizleri Standart Metot 4500 B Makro Kjeldahl metodu kullanilarak yapılmıştır. $\mathrm{NH}_{3}-\mathrm{N}$ analizleri Standart Metot $4500 \mathrm{NH}_{3} \mathrm{~B}-\mathrm{C}$; $\mathrm{NO}_{3}^{-}-\mathrm{N}$ ve $\mathrm{NO}_{2}^{-}-\mathrm{N}$ analizleri Standart Metot 4110 B kapsamında yapılmıştır [8]. Çözünmüş organik azot, Kjeldahl ve amonyak azotunun farkından hesaplanmıştır.

Alınan atıksu örnekleri, Khan ve ark. [6] tarafından geliştirilen ve Şimşek ve ark. [5] tarafından bazı modifikasyonları yapılan prosedüre göre inkübasyona tabi tutulmuştur. Bu yöntemde hacimde amber inkübasyon şişesine 200'er mL atıksu örnekleri eklenmiş ve $2 \mathrm{~mL}$ tesisten temin edilen karışık bakteri kültürü içeren ham atıksu ilave edilmiştir. İnkübasyon prosedürüne $20^{\circ} \mathrm{C}$ 'de 28 gün boyunca devam edilmiştir. İnkübatörde $80 \mathrm{rpm}$ hızda karıştırma sağlanmış ve aerobik koşulların hâkim olması için her gün şişelerin kapakları açılarak havalandırması sağlanmıştır. Atıksu örneklerine uygulanan işlemlerin aynısı deiyonize suya da uygulanmış ve 28 gün boyunca bu kontrol örnekleri için de aynı prosedür uygulanmıştır. İnkübasyon sonrasında biyolojik olarak parçalanabilen çözünmüş organik azot (BÇOA), fraksiyonu Eşitlik 1'e göre hesaplanmıştır.

$$
\mathrm{BÇOA}=\left(\mathrm{ÇOA}_{\mathrm{a}}-\mathrm{ÇOA}_{\mathrm{b}}\right)-\left(\mathrm{ÇOA}_{\mathrm{ka}}-\mathrm{ÇOA}_{\mathrm{kb}}\right)
$$

$\mathrm{ÇOA}_{a}$ ve $\mathrm{ÇOA}_{b}$ sırasıyla inkübasyondan önce ve sonra atıksu örneklerinde analiz edilen ÇOA konsantrasyonudur. $\mathrm{ÇOA}_{\mathrm{ka}}$ ve $\mathrm{CCOA}_{\mathrm{kb}}$ ise sırasıyla inkübasyon öncesi ve sonrasında kontrol örnekleri için analiz edilen ÇOA konsantrasyonudur.

\section{Sonuçlar}

Atıksu arıtma tesisi N1, N2 ve N3 noktalarından Ağustos, Eylül ve Ekim aylarında alınan örneklerde yapılan analizler sonucu toplam çözünmüş azot konsantrasyonları Şekil 1'de verilmiştir. N1 noktasında 20,5-63 mg/L, N2 ve N3 noktalarında ise 23,8-34,4 mg/L aralığında değerler elde edilmiştir. Ağustos ve Eylül aylarında alınan örneklerde tesiste toplam çözünmüş azot parametresi için biyolojik arıtım ünitesinde \%60 verim elde edildiği tespit edilmiş, ancak Ekim ayında biyolojik arıtım ünitesi giriş ve çıkışında kayda değer bir toplam çözünmüş azot değişimi gözlemlenmemiştir. Bu durumun atıksu arıtma tesisinin öncelikle karbon giderimi, azotun kısmi giderimi odaklı tasarımıyla ilişkili olduğu düşünülmektedir. Literatüre göre ham evsel atıksularda toplam azot konsantrasyonu 20-85 mg/L, çözünmüş organik azot konsantrasyonu 8-35 mg/L, amonyak azotu konsantrasyonu 12-50 mg/L aralığında değişir; nitrit ve nitrat azotu konsantrasyonları ise oldukça düşüktür [9].

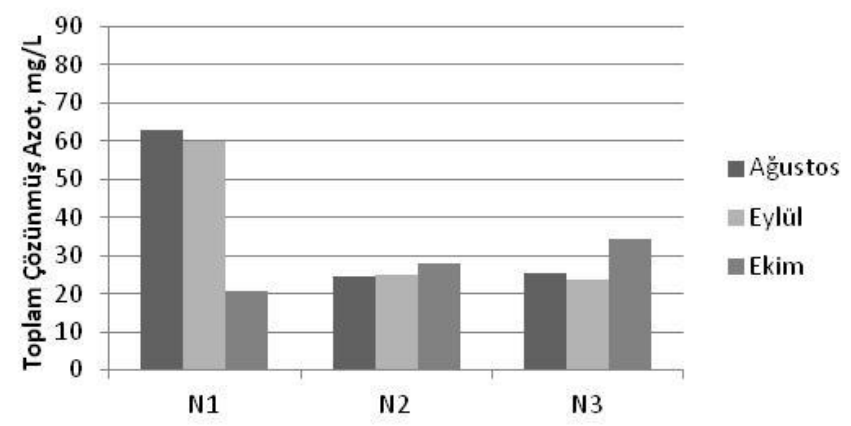

Şekil 1. N1, N2 ve N3 örnekleme noktalarında toplam çözünmüş azot konsantrasyonlarının değişimi.

Şekil 2'de üç örnekleme noktası için, farklı aylarda alınan örneklerde analiz edilen nitrat konsantrasyonları verilmiştir. $\mathrm{Bu}$ kategoride alınan örneklerin tamamında nitrit konsantrasyonları tespit limitlerinin altında bulunmuştur. Ön arıtım çıkışında örnekleme yapılan tüm aylar için nitrat konsantrasyonu 0,65-0,74 mg/L aralığında tespit edilmiştir. Biyolojik arıtım ünitesinden Eylül ayında alınan örnekte nitrat konsantrasyonu 12,61 mg/L olarak belirlenmiş, ancak diğer aylarda bu değer çok daha düşük bulunmuştur. Eylül ayında arıtma tesisinde diğer aylara nispeten oldukça yüksek konsantrasyonda çözünmüş organik azot değeri (N1 noktasında $56.76 \mathrm{mg} / \mathrm{L}$ ) gözlenmiştir ve buna bağlı olarak da, biyolojik arıtım ünitesinde girişte düşük amonyak azotu konsantrasyonuna rağmen, çözünmüş organik azotun amonifikasyonundan kaynaklı yüksek nitrat konsantrasyonunun oluştuğu düşünülmektedir. Ağustos ayı için N2 noktasında nitrat azotu konsantrasyonlarının 
düşük olması biyolojik arıtım havuzunun ilk aerobik bölümünde başarılı bir nitrifikasyon olmadığını göstermektedir. Son çökeltme ünitesi çıkışında nitrat konsantrasyonları beklenildiği üzere 0,56-1,31 mg/L aralı̆̆ında elde edilmiştir.

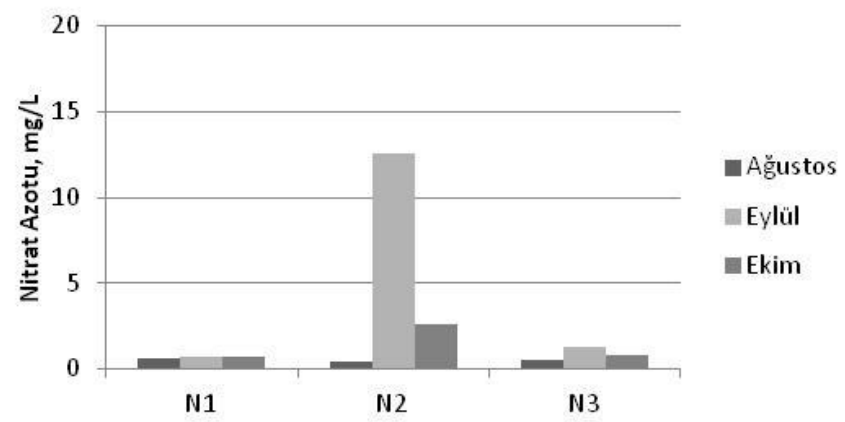

Şekil 2. N1, N2 ve N3 örnekleme noktalarında nitrat azotu konsantrasyonlarının değişimi.

Üç farklı örnekleme noktası için Ağustos, Eylül ve Ekim aylarında belirlenen amonyak azotu konsantrasyonları Şekil 3'de gösterilmiştir. N1 noktasında elde edilen amonyak azotu konsantrasyonları 2,24$53,7 \mathrm{mg} / \mathrm{L}$ aralığındadır ve bu parametre N2 ve N3 noktaları için sırasıyla 2,0-23,7 mg/L ve 2,8-24,5 mg/L aralığında tespit edilmiştir. Eylül ayında her üç noktadan alınan örneklerde, diğer iki örneğe göre çok düşük amonyak azotu konsantrasyonları tespit edilmiştir. Ağustos ayında alınan örneklerde ön çökeltme sonrası 53,7 mg/L düzeyinde olan amonyak azotu, biyolojik arıtım ünitesinde \%61 oranında giderilmiştir ve bu durumda biyolojik arıtım ünitesinin ilk basamağında başarılı bir nitrifikasyon işleminin yapıldı̆̆ı söylenebilir.

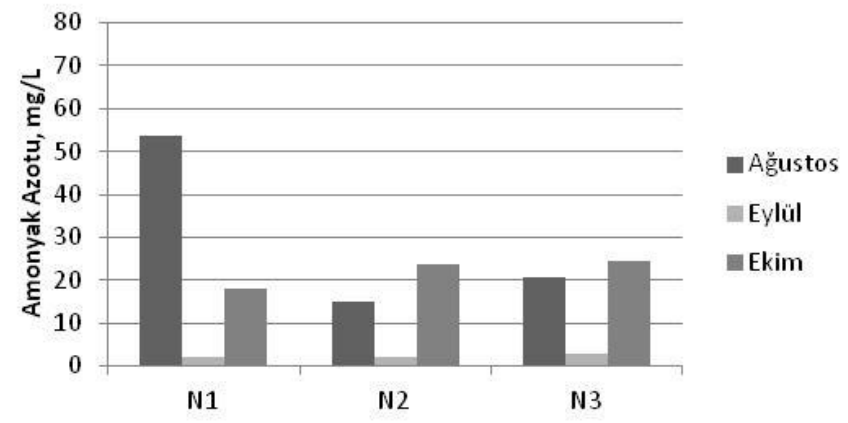

Şekil 3. N1, N2 ve N3 örnekleme noktalarında amonyak azotu konsantrasyonlarının değişimi.

Örnekleme noktalarında farklı aylarda tespit edilen çözünmüş organik azot konsantrasyonları Şekil 4'de gösterilmiştir. Ağustos ve Ekim aylarında çözünmüş organik azot değerleri 1,7-9,1 mg/L aralığında değişmekte ve toplam çözünmüş azot \%6-36,7 aralığında iken, Eylül ayında alınan örneklerde oldukça yükselmiştir. Özellikle ön çökeltme tankı çıkışında çözünmüş organik azot konsantrasyonu 56,76 mg/L olarak tespit edilmiştir ve bu değer toplam çözünmüş azotun \%95'ini oluşturmaktadır. Biyolojik arıtım ünitesinde Ağustos ve Eylül aylarında sırasıyla \%52 ve \%65 çözünmüş organik azot giderimi sağlanmış, Ekim ayında ise giderim gözlenmemiştir. Bardeonpho prosesi biyolojik arıtım ünitesi bulunan bir atıksu arıtma tesisinde yapılan bir çalışmada [4], ilk anoksik bölmede çözünmüş organik azot değerinde bir artış görülmüş ve daha sonraki ünitelerde bir giderim olmamıştır. Bu durumun anoksik biyolojik aktivite veya heterotofik denitrifikasyondan kaynaklanabileceği belirtilmiştir. 


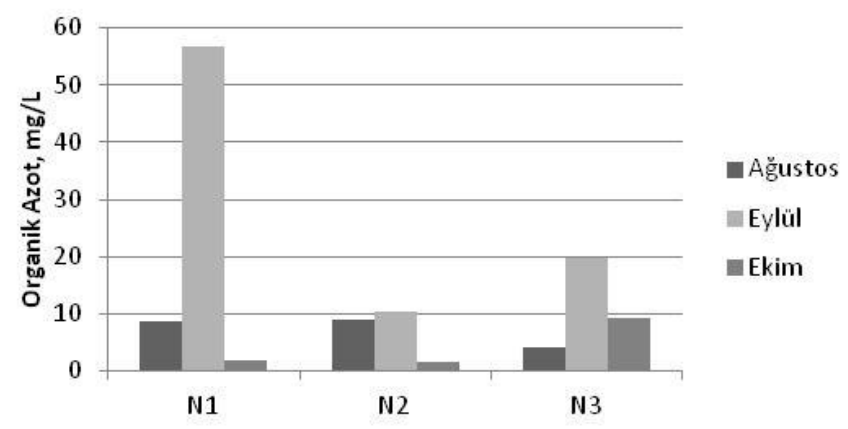

Şekil 4. N1, N2 ve N3 örnekleme noktalarında çözünmüş organik azot konsantrasyonlarının değişimi.

Ön arıtım çıkışında alınan örneklerde (N1) toplam çözünmüş azot içerisinde en baskın azot türü Ağustos ve Ekim aylarında sırasıyla \%85,3 ve \%87,2 ile amonyum azotu olarak tespit edilmiştir. Ancak Eylül ayında alınan örnekte en yüksek oran (\%95) çözünmüş organik azot türüne aittir. N2 noktasından alınan örneklerde farklı zamanlarda alınan örneklerde farklı azot türlerinin daha baskın olduğu söylenebilir. Ağustos ayında toplam çözünmüş azotun \%61,5'i amonyum azotu, \%36,7'si çözünmüş organik azottan oluşmaktadır. Eylül ayı örneğinde toplam çözünmüş azot içerisinde \%50,6 nitrat azotu ve \%41,3 çözünmüş organik azot mevcuttur. Ekim ay1 için ise toplam çözünmüş azotun \%84,7'si amonyum azotundan oluşmaktadır. N3 örnekleme noktasında Ağustos ve Ekim aylarında toplam çözünmüş azotun sırasıyla \%81,7 ve \%71,2'si amonyum azotu ve sırasıyla \%16,1 ve \%26,4'ü çözünmüş organik azottan müteşekkildir. Ancak Eylül ayında alınan örnekte çözünmüş organik azot toplam çözünmüş azotun \%82,7'sini oluşturmaktadır. Özetle ÇOA/TÇA değerleri N1 için \%9,3-95, N2 için \%6,1-41,3 ve N3 için \%16,1-82,7 aralığında tespit edilmiştir.

Dört basamaklı Bardenpho prosesinde karbon oksidasyonu, nitrifikasyon ve denitrifikasyon işlemleri gerçekleştirilir ve denitrifikasyonun gerçekleşebilmesi için hem atıksudaki karbon, hem de içsel solunum hidrolizi sonucu oluşan karbon kullanılmaktadır. İlk anoksik ortamda atıksudaki karbon nitratın denitrifikasyonunda kullanılmakta ve atıksudaki amonyak azotu miktarında değişiklik olmamaktadır. İlk aerobik tankta nitrifikasyon gerçekleşmekte ve ikinci anoksik bölümde içsel solunum ile karbon sağlanarak, ilave denitrifikasyon gerçekleştirilmektedir. İkinci aerobik bölmede çökeltme işlemi öncesinde azot gazı sistemden uzaklaştırılmaktadır [10].

$\mathrm{Bu}$ çalışmada örneklerin alındığı atıksu arıtma tesisi karbon giderimi ve kısmi azot giderimini hedefleyen ileri biyolojik arıtımın yapıldığı bir tesistir. Tesisten Ağustos ayında tüm örnekleme noktalarından alınan örneklerde en baskın azot türü amonyak azotu olarak tespit edilmiştir. Çözünmüş organik azot parametresi ise biyolojik arıtım girişinde $8,6 \mathrm{mg} / \mathrm{L}$ iken son çökeltme çıkışında 4,1 mg/L olarak belirlenmiştir ve bu sonuçlar çözünmüş organik azotun \%52 oranında giderildiğini göstermektedir. N2 noktasında alınan örnekte analiz edilen değerlerle kıyaslandığında, N3 noktasında çözünmüş organik azotta azalma ve amonyak azotunda bir miktar artma gözlemlenmiştir; bu durumun çözünmüş organik azotun parçalanması sonucu önce amonyağa dönüşmesinden kaynaklandığı düşünülmektedir. Nitrit azotu tespit limitlerinin altında ve nitrat azotu konsantrasyonu N1, N2 ve N3 noktalarında düşük konsantrasyonlardadır (0,46-0,65 mg/L aralığında). Biyolojik arıtım girişinde $53,7 \mathrm{mg} / \mathrm{L}$ konsantrasyonundaki amonyak azotu çıkışta $20,8 \mathrm{mg} / \mathrm{L}$ değerine düşmektedir. İlk anoksik ve aerobik bölmenin çıkışında amonyak azotu konsantrasyonunun azalması ve nitrit, nitrat azotlarının konsantrasyonlarının dikkate değer bir değişime uğramaması nedeniyle, nitrifikasyon-denitrifikasyon işlemlerinin burada tamamlandığı ve ikinci anoksik-aerobik bölmelerde çözünmüş organik azot gideriminin yapıldı̆̆ı söylenebilir.

Eylül ayında alınan örneklerde atıksuyun amonyak azotu konsantrasyonu tüm örnekleme noktalarında 2,022,8 mg/L aralığındandır ve biyolojik arıtım girişinde çözünmüş organik azot konsantrasyonu 56,76 mg/L değerinde tespit edilmiştir. Bu durum Ağustos ayına göre bu örneklerde ham atıksuyun azot içeriğinin değiştiğini göstermektedir. Tesis evsel atıksuların yanı sıra endüstriyel atıksuların da arıtımını gerçekleştirmektedir ve bu örnekleme zamanında atıksu içeriğinde buna bağlı bir değişiklik olduğu düşünülmektedir. Son çökeltme çıkışında analiz edilen çözünmüş organik azot konsantrasyonu, tesiste biyolojik arıtımda \%65 çözünmüş organik azot gideriminin sağlandığını ifade etmektedir. Bardenpho prosesi girişinde $0,72 \mathrm{mg} / \mathrm{L}$ olan nitrat azotu 
konsantrasyonunun ilk aerobik bölme çıkışında $12,61 \mathrm{mg} / \mathrm{L}$ 'ye yükselmesi nitrifikasyon işleminin sonucudur. Biyolojik arıtım çıkışında bu değerin 1,31 mg/L'ye düşmesi denitrifikasyondan kaynaklanmaktadır.

Ekim ayında tesisten alınan örneklerde, Ağustos ayındaki örneklerle benzer şekilde baskın azot türü amonyak azotudur, ancak biyolojik arıtım girişinde konsantrasyon $17,9 \mathrm{mg} / \mathrm{L}$ 'dir. Biyolojik arıtım sonrasında bu değer $24,5 \mathrm{mg} / \mathrm{L}$ 'ye bir miktar yükselmiştir. N2 noktasında nitrat azotu konsantrasyonunun $2,57 \mathrm{mg} / \mathrm{L}$ 'ye yükselmesi bir miktar nitrifikasyonun gerçekleştĭgini göstermektedir. Ancak biyolojik arıtım ünitesinde çözünmüş organik azot miktarında bir artış olmuş ve amonyak miktarı önemli düzeyde bir değişiklik göstermemiştir.

Dört basamaklı bir Bardenpho prosesini bulunduğu bir atıksu arıtma tesisinde yapılan bir çalışmada [4], tesisin farklı noktalarından alınan örneklerde azot türlerinin dağılımı incelenmiş ve ilk aerobik bölmeye kadar en baskın tür amonyak azotu, daha sonraki bölmelerde ise nitrat azotu olarak belirlenmiştir. İlk anoksik bölmede bir önceki basamağa göre daha düşük nitrat azotu konsantrasyonu tespit edilmiş ve bunun denitrifikasyondan kaynaklandığı belirtilmiştir. Bu bölmede amonyak azotu konsantrasyonu stabildir. Son aerobik bölmede nitrifikasyondan dolayı amonyak azotu tespit edilmemiştir.

Nitrifikasyon işleminin karbon gideriminin de yapıldığı sistemlerde sağlanabilmesi için işletme koşullarının iyi dengelenmesi gerekmektedir. Katı alıkonma süresi, F/M oranı, sıcaklık, çözünmüş oksijen düzeyi, pH ve BOİ/Toplam Kjeldahl Azotu yükü gibi bazı parametreler nitrifikasyonun sürecini etkileyen parametrelerdir [9].

28 günlük inkübasyon işleminden sonra örneklerde analiz edilen toplam çözünmüş azot konsantrasyonları Şekil 5'te verilmiştir. Ağustos ayı için bu değer 36,27-81,12 mg/L, Eylül ayı için 5,27-10,45 mg/L ve Ekim ay1 için 21,66-36,12 mg/L aralıklarında tespit edilmiştir.

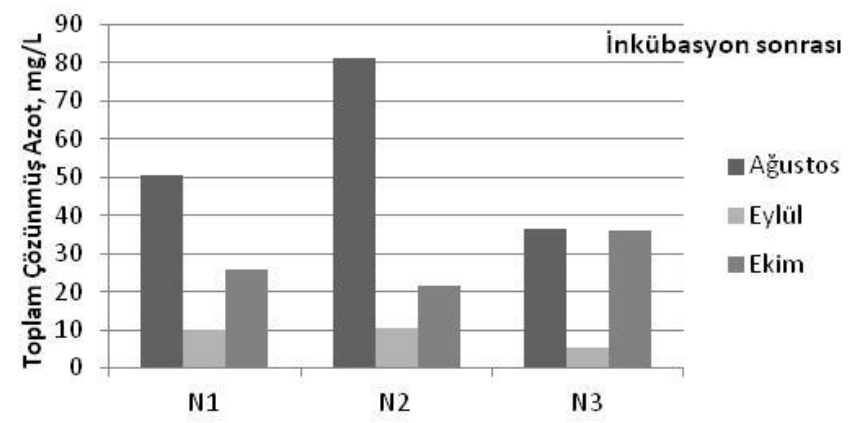

Şekil 5. İnkübasyon sonrası N1, N2 ve N3 örnekleme noktalarında toplam çözünmüş azot konsantrasyonlarının değişimi.

Şekil 6'da inkübasyon işlemi sonrası örneklerde analiz edilen nitrat azotu konsantrasyonları verilmiş̧ir. N1 noktasında $0,65-0,74 \mathrm{mg} / \mathrm{L}$ aralı̆ğında olan nitrat azotu konsantrasyonu, inkübasyon sonrası $0,74-2,45 \mathrm{mg} / \mathrm{L}$ aralığına gelmiştir. N2 noktasından alınan örneklerde ise inkübasyon neticesinde Ağustos ayında $0,46 \mathrm{mg} / \mathrm{L}$ konsantrasyonundan 4,40 mg/L'ye, Ekim ayında ise 2,57 mg/L'den 18,1 mg/L'ye yükselmiştir. Eylül ayında ise inkübasyondan önce $12,61 \mathrm{mg} / \mathrm{L}$ olan nitrat azotu konsantrasyonu $5,02 \mathrm{mg} / \mathrm{L}$ değerine düşmüsstür. N3 noktasından Ağustos, Eylül ve Ekim aylarında alınan örneklerde sırasıyla 0,56, 1,31 ve 0,82 $\mathrm{mg} / \mathrm{L}$ olan nitrat azotu konsantrasyonları inkübasyon ile yine sırasıyla $1,17,1,52$ ve $0,72 \mathrm{mg} / \mathrm{L}$ konsantrasyonlarına gelmiştir. İnkübasyon sonrasında nitrat konsantrasyonlarındaki artış, örneklerdeki mevcut amonyağın ve/veya inkübasyon boyunca çözünmüş organik azotun amonifikasyonundan açığa çıkan amonyağın nitrifikasyonundan kaynaklanmaktadır [5]. 


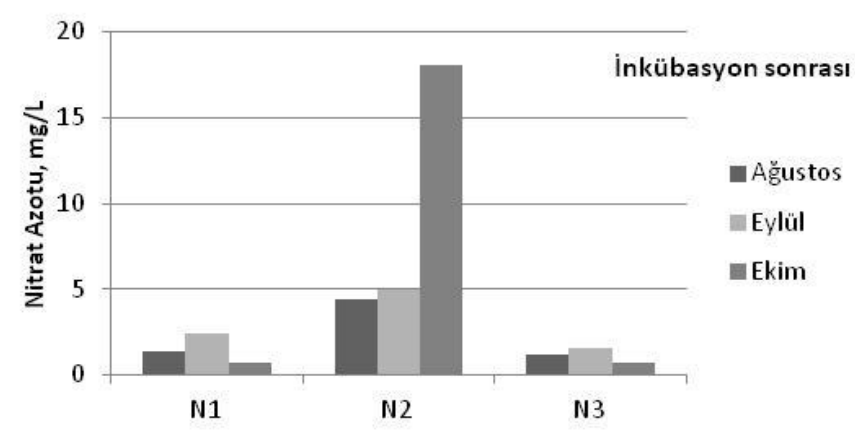

Şekil 6. İnkübasyon sonrası N1, N2 ve N3 örnekleme noktalarında nitrat azotu konsantrasyonlarının değişimi.

İnkübasyon öncesinde alınan örneklerin tamamında analiz edilen nitrit azotu konsantrasyonu tespit limitlerinin altındadır. Ancak inkübasyon sonrasında N2 örnekleme noktasına ait Ağustos ve Eylül aylarının örneklerinde sırasıyla 2,11 ve 1,67 mg/L nitrit azotu tespit edilmiştir (Şekil 7). 2102 yılında ABD'de iki basamaklı bir damlatmalı filtre ünitesinde yapılan çalışmada [5], başlangıçta $0,1 \mathrm{mg} / \mathrm{L}$ 'den daha düşük konsantrasyonlarda olan nitrit konsantrasyonları inkübasyon sonrasında birincil çökeltme öncesi ve sonrasında 25,2 ve 22,9 mg/L düzeylerinde bulunmuştur. Nitrat konsantrasyonlarının aynı örneklerde 3 ve 4,6 mg/L olarak tespit edilmesi ortamda yeterli çözünmüş oksijenin bulunmaması ile ilişkilendirilmiştir. Ancak söz konusu tesiste başlangıçta 23,8 mg/L amonyak azotunun tamamı giderilebilmektedir.

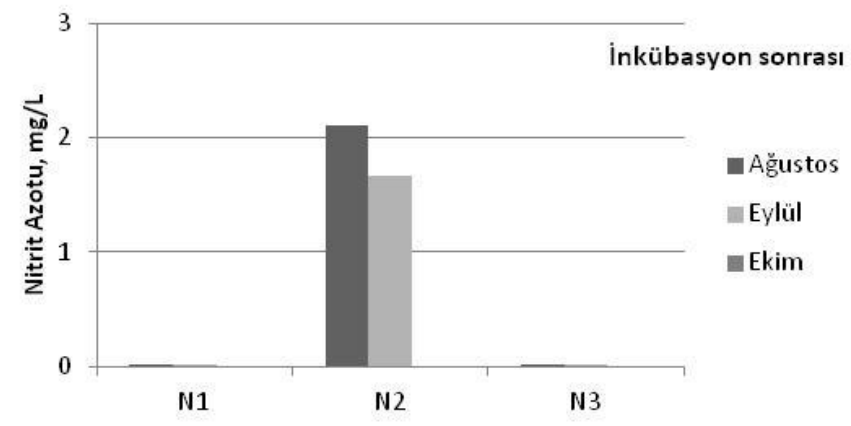

Şekil 7. İnkübasyon sonrası N1, N2 ve N3 örnekleme noktalarında nitrit azotu konsantrasyonlarının değişimi.

Şekil 8'de inkübasyon işlemi sonrası örneklerde tespit edilen amonyak azotu konsantrasyonları verilmiştir. İnkübasyon işlemi sonrasında amonyak azotu konsantrasyonlarında genellikle bir azalma gözlemlenmiş, ancak biyolojik arıtım giriş suyunda 53,7 mg/L amonyak azotunun tespit edildiği Ağustos ayı örneklerinde, N2 ve N3 örnekleme noktalarına ait inkübasyon işlemlerinin sonunda amonyak azotu konsantrasyonlarında artış gözlemlenmiştir. Daha önce ABD'de yapılan bir çalışmada [5] inkübasyon sonrası amonyak azotunun birkaç örnek haricinde tamamında nitrifikasyona uğradığı tespit edilmiştir. 2013 yılında yapılan bir çalışmada [2], inkübasyon işlemi hem ayrı ayrı bakteri ve alg kültürü hem de bakteri kültürü ve alglerle birlikte gerçekleştirilmiş, sonuçta sadece alg kültürünün kullanıldığı inkübasyon işlemi sonrasında kalıntı amonyak tespit edilmiştir ve bunun sebebinin inkübasyon boyunca alg kültürünün faydalanamayacağı amonyaktan kaynaklandığı belirtilmiştir. 


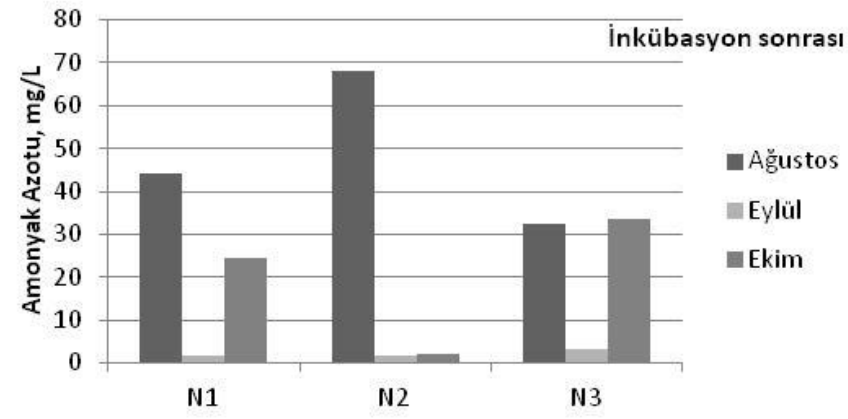

Şekil 8. İnkübasyon sonrası N1, N2 ve N3 örnekleme noktalarında amonyak azotu konsantrasyonlarının değişimi.

Şekil 9'da inkübasyon neticesinde çözünmüş organik azot konsantrasyonları aylara ve örnekleme noktalarına göre verilmiştir. Tüm örneklerde inkübasyon sonrası çözünmüş organik azot konsantrasyonlarında bir azalma tespit edilmiştir. İnkübasyon sonrası çözünmüş organik azot miktarındaki azalmanın fazla oluşu, çözünmüş organik azotun biyolojik olarak kullanılabilirliğinin yüksek oluşunu veya kolay parçalanamayan çözünmüş organik azot formunun daha az miktarda oluşunu göstermektedir [2].

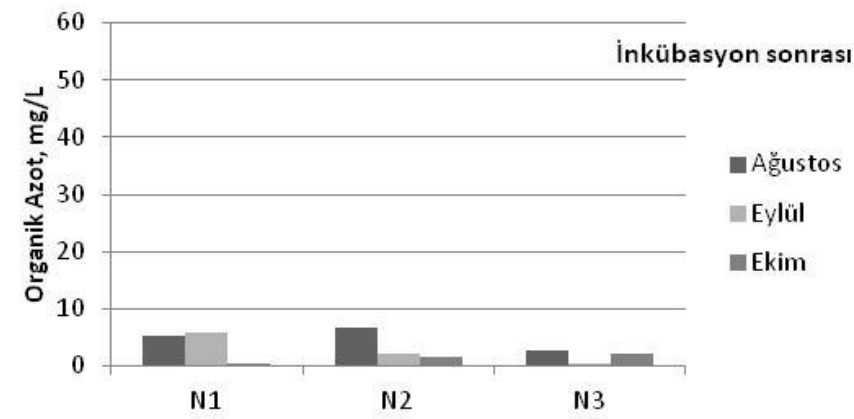

Şekil 9. İnkübasyon sonrası N1, N2 ve N3 örnekleme noktalarında çözünmüş organik azot konsantrasyonlarının değişimi.

N2 noktasındaki Ağustos ve Eylül ayı örnekleri dışında (sırasıyla 2,11 ve 1,67 mg/L) inkübasyon sonrasında nitrit konsantrasyonları tespit limitlerinin altında elde edilmiştir. N1 örnekleme noktasında inkübasyon sonrası en yüksek oranda Ağustos ve Ekim ayları için amonyak azotu konsantrasyonu, Eylül ayı için ise çözünmüş organik azot tespit edilmiştir. Eylül ayında biyolojik arıtım ünitesi girişindeki, diğer aylara göre çok yüksek konsantrasyondaki $(56,76 \mathrm{mg} / \mathrm{L})$ çözünmüş organik azotun bu sonuçta etkili olduğu düşünülmektedir. N2 örnekleme noktasında inkübasyon sonrası Eylül ve Ekim aylarındaki örneklerde en baskın tür nitrat azotudur, Ağustos ayında ise amonyak azotudur. Ağustos ayında alınan örnekte biyolojik arıtım girişinde yüksek amonyak azotu konsantrasyonu $(53,7 \mathrm{mg} / \mathrm{L})$ nitrifikasyon işlemindeki başarıyı etkilemiştir. N3 noktasında alınan örneklerde yapılan inkübasyon işlemi sonrasında tüm örneklerde en fazla görülen azot türü amonyak azotudur.

Şekil 10'da inkübasyon prosedürü ile belirlenen farklı örnekleme noktalarındaki BÇOA konsantrasyonları verilmiştir. Biyolojik arıtım girişinde $56,76 \mathrm{mg} / \mathrm{L}$ çözünmüş organik azotun tespit edildiği Eylül ayı örneği dışında diğer aylarda BÇOA konsantrasyonu 0,44-7,29 mg/L aralığında belirlenmiştir. Eylül ayına ait örneklerde ise N1 noktasında 51,08 mg/L, N2'de 8,4 mg/L ve N3'de 19,39 mg/L olarak belirlenmiştir. Tesiste biyolojik arıtım ünitesi girişinden son çökeltme tankı çıkışına kadar BÇOA parametresi giderim verimi Ağustos ve Eylül ayları için sırasıyla \%53 ve \%62 olarak elde edilmiş, Ekim ayında ise BÇOA'de ikinci anoksik ve aerobik bölmede artış olduğu gözlemlenmiştir. Simsek ve arkadaşları tarafından 2012 yılında iki kademeli bir damlatmalı filtre tesisinde yapılan çalışmada da [5], ham atıksuda ve tesis çıkışında sırasıyla 6,2 ve 1,8 mg/L BÇOA değerleri tespit edilmiştir. Söz konusu çalışmada BÇOA gideriminin BOİ damlatmalı filtrelerinde, 
nitrifikasyon damlatmalı filtrelerinde ve klorlama ünitesinde olduğu belirtilmiştir. Yapılan bir çalışmada [2], saf oksijenli aktif çamur ve hareketli yatak biyofilm reaktör bulunan bir atıksu arıtma tesisinde BÇOA giderimi \%68 olarak belirlenmiştir.

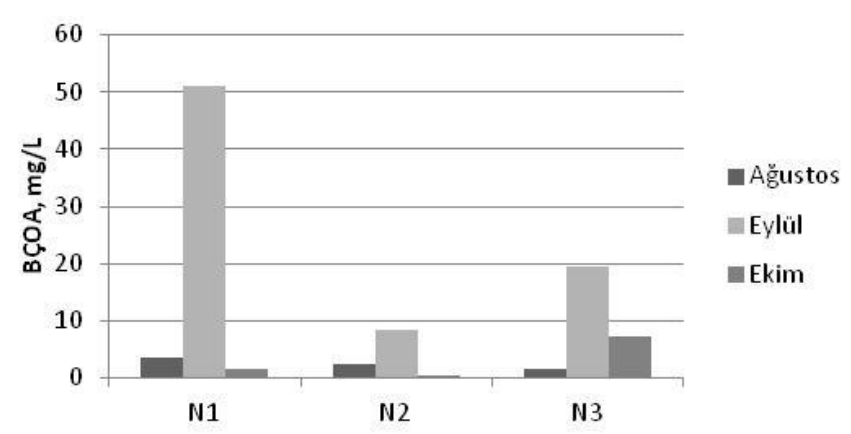

Şekil 10. N1, N2 ve N3 örnekleme noktalarında BÇOA konsantrasyonlarının değişimi.

N1, N2 ve N3 örnekleme noktaları için belirlenen BÇOA konsantrasyonlarının toplam çözünmüş organik azota oranları Şekil 11'de gösterilmiştir. Biyolojik arıtım girişinde yüksek çözünmüş organik azotun tespit edildiği Eylül ayında çözünmüş organik azotun biyolojik parçalanabilirliği N1, N2 ve N3 noktaları için sırasıyla \%90, \%82 ve \%98 olarak belirlenmiştir. Ağustos ayında N1 ve N3 noktalarında sırasıyla \%42 ve \%41 çözünmüş organik azot biyolojik parçalanabilirliği tespit edilmiş ve N2 noktasında bu değer \%28'e düşmüştür. Ekim ayında da Ağustos ayına benzer bir eğilim belirlenmiş ve N1 noktasında çözünmüş organik azotun biyolojik parçalanabilirliği \%86 iken, N2'de \%26 ve N3'de \%80 bulunmuştur. Üç örnekleme ayında da ortak eğilim biyolojik parçalanabilirliğin biyolojik arıtım giriş ve çıkışında yüksek oluşu, ancak ilk anoksik ve aerobik bölmenin sonundan alınan örnekte bu değerin düşük elde edilmesidir. Literatürde iki kademeli bir damlatmalı filtre tesisinde farklı arıtım basamaklarında BÇOA/ÇOA oranı \%51-69 arasında tespit edilmiştir [5]. Tesis çıkış suyunda ise biyolojik parçalanabilirlik \%52 [5] ve \%45 [2] bulunmuştur. Literatürde biyolojik parçalanabilirliğin arıtım hattı boyunca dereceli olarak azaldığ 1 belirlenmiştir [2, 5]. Şekil 12'de toplam çözünmüş azot içerisinde biyolojik parçalanabilme özelliğine sahip çözünmüş organik azot yüzdelerini göstermektedir. Yüksek çözünmüş organik azot girişinin olduğu Eylül ayında bu oran \%86 değerine kadar yükselmiş iken, diğer aylarda \%1,6 değerine kadar düşebilmektedir. BÇOA/TÇA oranlarında görülen eğilim, Şekil 19'da verilen BÇOA/ÇOA oranları ile benzerlik göstermektedir.

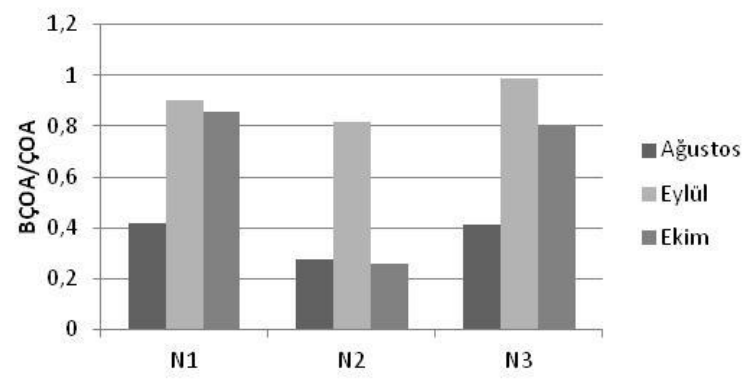

Şekil 11. N1, N2 ve N3 örnekleme noktalarında BÇOA/ÇOA oranının değişimi.

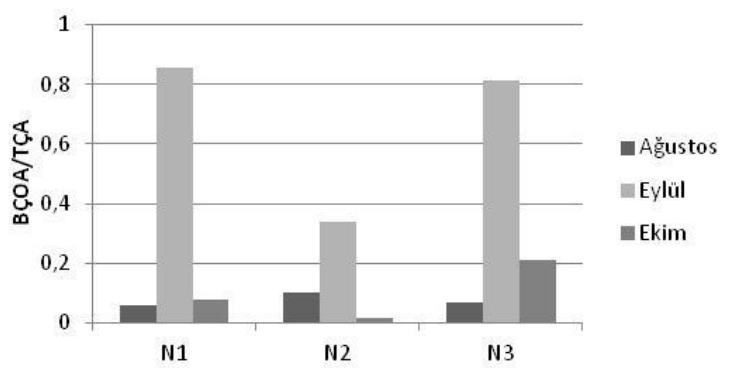

Şekil 12. N1, N2 ve N3 örnekleme noktalarında BÇOA/TÇA oranının değişimi.

\section{Tartışma}

Bu çalışmada kısmi azot giderimi yapılan bir atıksu arıtma tesisindeki çözünmüş organik azotun biyolojik olarak parçalanabilirliğinin incelenmesi amaçlanmıştır. Atıksu arıtma tesisi N1, N2 ve N3 noktalarından Ağustos, Eylül ve Ekim aylarında alınan örneklerde uygulanan inkübasyon işlemi sonrasında biyolojik arıtım 
girişinde $56,76 \mathrm{mg} / \mathrm{L}$ çözünmüş organik azotun tespit edildiği Eylül ayı örneği dışında diğer aylarda BÇOA konsantrasyonu 0,44-7,29 mg/L aralı̆ı̆ında belirlenmiştir. Eylül ayına ait örneklerde ise N1 noktasında 51,08 $\mathrm{mg} / \mathrm{L}$, N2'de 8,4 mg/L ve N3'de 19,39 mg/L olarak belirlenmiştir. Tesiste biyolojik arıtım ünitesi girişinden son çökeltme tankı çıkışına kadar BÇOA parametresi giderim verimi Ağustos ve Eylül ayları için sırasıyla \%53 ve $\% 62$ olarak elde edilmiş, Ekim ayında ise BÇOA'da ikinci anoksik ve aerobik bölmede artış olduğu gözlemlenmiştir. Biyolojik arıtım girişinde yüksek çözünmüş organik azotun tespit edildiği Eylül ayında çözünmüş organik azotun biyolojik parçalanabilirliği N1, N2 ve N3 noktaları için sırasıyla \%90, \%82 ve \%98 olarak belirlenmiştir. Ağustos ayında N1 ve N3 noktalarında sırasıyla $\% 42$ ve $\% 41$ çözünmüş organik azot biyolojik parçalanabilirliği tespit edilmiş ve N2 noktasında bu değer \%28'e düşmüştür. Ekim ayında da Ağustos ayına benzer bir eğilim belirlenmiş ve N1 noktasında çözünmüş organik azotun biyolojik parçalanabilirliği \%86 iken, N2'de \%26 ve N3'de \%80 bulunmuştur. Üç örnekleme ayında da ortak eğilim biyolojik parçalanabilirliğin biyolojik arıtım giriș ve çıkıșında yüksek oluşu, ancak ilk anoksik ve aerobik bölmenin sonundan alınan örnekte bu değerin düşük elde edilmesidir.

Toplam çözünmüş azot içerisinde biyolojik parçalanabilme özelliğine sahip çözünmüş organik azot yüzdeleri yüksek çözünmüş organik azot girişinin olduğu Eylül ayında bu oran $\% 86$ değerine kadar yükselmiş iken, diğer aylarda \%1,6 değerine kadar düşebilmektedir. BÇOA/TÇA oranlarında görülen eğilim, $\mathrm{BÇOA} / C ̧ \mathrm{OA}$ oranları ile benzerlik göstermektedir.

Kullanılabilir su kaynaklarının her geçen gün azalması, mevcut su kaynaklarının korunmasının önemini arttırmaktadır. Mevcut su kaynaklarının korunması için azot ve fosfor kontrolü büyük önem taşımaktadır. İnorganik ve çözünmüş organik azot bileşiklerinin alıcı su ortamlarında meydana getirdiği kirlilik önemli boyutlara varabilmektedir. Türkiye'de yasal sınırlandırmalar, toplam azot, nitrit, nitrat ve amonyak azotu için, ayrıca toplam Kjeldahl azotu için bulunmaktadır. Ancak atıksu arıtma tesislerinde inorganik azot formları etkili bir şekilde giderilirken, çözünmüş organik azot türleri daha düşük etkinlikle giderilebilmekte, bu durum da tesis çıkış sularında toplam azot parametresinin büyük bir kısmını çözünmüş organik azotların oluşturmasına neden olmaktadır. Bu nedenle atıksu arıtma tesislerinin çıkış sularında çözünmüş organik azotun ve biyolojik olarak bozunabilirliğinin takip edilmesi ve tesiste üniteler bazında gideriminin incelenmesi, alıcı su ortamlarında istenmeyen çevresel problemlerin önüne geçilmesine katkı sağlayacaktır. Bu çalışmanın sonuçları, diğer atıksu arıtma tesislerindeki giderim verimliliğinin incelenmesi ve yeni yasal sınırlandırmaların getirilebilmesi konusuna 1şık tutacaktır.

\section{Teşekkür}

Bu çalışma Ayşe Sevil'in Yüksek lisans tezinden üretilmiştir ve Selçuk Üniversitesi Bilimsel Araştırma Projeleri (BAP) Koordinatörlüğü tarafından 15201092 no.lu proje ile desteklenmiştir.

\section{Kaynaklar}

[1] Pehlivanoglu-Mantas E, Sedlak DL. Wastewater-Derived dissolved organic nitrogen: analytical methods, characterization and effect-A review. Critical Reviews in Environmental Science and Technology 2006; 36: 261-285.

[2] Simsek H, Kasi M, Ohm J-B, Blonigen M, Khan E. Bioavailable and biodegradable dissolved organic nitrogen in activated sludge and trickling filter wastewater treatment plants. Water Res. 2013; 47: 3201-3210.

[3] Pehlivanoglu-Mantas E, Sedlak DL. Bioavailability of wastewater-derived organic nitrogen to alga Selenastrum capricornutum. Water Res. 2004; 38: 3189-3196.

[4] Sattayatewa C, Pagilla K, Pitt P, Selock K, Bruton T. Organic nitrogen transformations in a 4-stage Bardenpho nitrogen removal plant and bioavailability/biodegradability of effluent DON. Water Res. 2009; 43: 4507-4516.

[5] Simsek H, Kasi M, Wadhawan T, Bye C, Blonigen M, Khan E. Fate of dissolved organic nitrogen in two stage trickling filter process. Water Res. 2012; 46: 5115-5126.

[6] Khan E, Awobamise M, Jones K, Murthy S. Method development for measuring biodegradable dissolved organic nitrogen in treated wastewater. Water Environ. Res 2009; 81: 779-787.

[7] Urgun-Demirtas M, Sattayatewa C, Pagilla KR. Bioavaliability of dissolved organic nitrogen in treated effluents. Water Environ. Res.2008; 80: 397-406.

[8] APHA/AWWA/WEF. Standard Methods for the Examination of Water and Wastewater. 21st ed. Washington DC, USA: American Public Health Association, 2005.

[9] Toprak H. Aktif Çamur Sürecinin İşletilmesi. 2. Baskı. İzmir, Türkiye: Dokuz Eylül Üniversitesi Yayınları, 2000.

[10] Metcalf and Eddy. Wastewater Engineering, Treatment and Reuse. Fourth ed. USA: McGraw-Hill International Editions, 2003. 